\title{
パーム油の環境への影響と 持続可能なパーム油に向けた取組みについて
}

\author{
関口静 雄 \\ （ライオン(株） 研究開発本部＼cjkstart企画管理部）
}

\section{1 はじめに}

パーム油の生産量は 2001 年には約 2,400万 t であった が, 2006 年になると 3,300 万 $\mathrm{t}$ を越え, 植物油脂として は大豆油を抜いて世界最大の生産量となった"”。この 2001 年から 2006 年までの 5 年間での植物油脂全体の生 産量の伸びは $28 \%$ あるるが, その中でもパーム油は 48\%と格段に大きく伸びている。このパーム油の大幅な 増産は, インド, 中国などアジアでの人口増加と経済発 展に伴う食生活の変化が, それまで食油として主流で あった大豆油やナタネ油に比較し安価なパーム油の需要 をもたらした。また，欧州でのBSE（狂牛病）による牛 脂代替あるいは米国でのトランス脂肪酸問題による大豆 油代替などもパーム油の需要増加に拍車を掛けたと考え られる。

パーム油の用途を2005 年度の世界消費量で見ると, 総消費量 3,200 万 $\mathrm{t}$ の内, 約 $80 \%$ に相当する 2,600 万 $\mathrm{t}$ が揚げ油, マーガリン, 食品加工用油脂などの食用で消 費されて抢り，金属石畧，プラスチック原料，タイヤ添 加剤などの工業用途が 15 ～17\%, 高級アルコールや界 面活性剂などの洗剂原料向けオレオケミカル用途が 1 $2 \%$ ，またバイオデイーゼル（軽油代替燃料）などのバ イオ燃料用が 1 ～ $2 \%$ と推定される ${ }^{2-4)}$ 。またパーム油に は天然カロチンなどの微量有用成分も含まれており, 健 康食品素材としても重要な油脂資源となっている。しか し一方で, 近年のパーム油の増産に関してはパーム栽培 に必要な農園開発が東南アジアの熱带雨林や泥炎地でも 行われて抢り, その場合は森林伐採時や乾燥した泥炭か ら大量の $\mathrm{CO}_{2}$ (炭酸ガス) の放出が起こりパーム油は環 境破壊に繋がると NPO 抒よびNGO から問題提起され ている。

連絡者: 関口静雄

E-mail : sizuseki@lion.co.jp
一方, 京都議定書での $\mathrm{CO}_{2}$ 削減の目標は $\mathrm{CO}_{2}$ 放出量 を1990 年以前のレベルに戻すことにある。この意味で すでに開発されている農園で製造されている油脂，すな わち, 欧米のナタネ油やダイズ油，㧍よび東南アジアで も既存の農園で製造されるパーム油は問題となっていな いが, ブラジルのアマゾンでの熱带雨林伐採によるダイ ズ畑の開発と東南アジアでの熱帯雨林伐採や泥炭地開発 によるパーム農園の開発など，ここ数年来急速に開発が 進んだものに対して歯止めを掛ける目的で問題提起され ているのが現状である。また，熱带地方の一部の農民の 間で慣習となっている野焼きや燒畑が引き起こす森林火 災や泥炭地火災で放出される大量の $\mathrm{CO}_{2}$ もパーム農園 開発に伴うものとして議論の対象となっている。

そこで, 本稿ではパーム油製造時（パームの種苗・栽 培からパーム果実の搾油まで）およびパーム農園開発に 伴う $\mathrm{CO}_{2}$ 放出量など $\mathrm{CO}_{2}$ の面からパーム油の環境への 影響を評価する。さらに，パーム油に関してNPO およ びNGO から指摘されている問題点を改善し, パーム油 をより環境に優しい将来的にも持続可能な植物原料とし ていくための RSPO (Roundtable on Sustainable palm Oil：持続可能なパーム油のための円卓会議）での取組 みについても概説する。

\section{2 パーム油の環境への影響評価}

パーム油の製造はパーム（別名アブラヤシとも呼ばれ ている）の種苗・栽培，果実の収穫拈よび搾油の一連の 工程で行われる。しかし，増産に向けては新たな農園開 発が必要になる。そこで本章では，パーム油に絘わる $\mathrm{CO}_{2}$ 放出量をパーム油製造（種苗・栽培から搾油まで） の部分と農園開発の部分に分け評価を行った。また, 熱 帯雨林を伐採しパーム農園化した時に樹木が吸収する大 気中の $\mathrm{CO}_{2}$ 量がどのように変化するか，野焼きや焼畑 で森林火災や泥炭地火災を引き起こした場合の $\mathrm{CO}_{2}$ 放 
出量についても併せて評価した。

(1)パーム油製造時の $\mathrm{CO}_{2}$ 放出量

・パーム種苗・栽培時（肥料，除草剂などの農薬の 使用）および収穫，搾油時の $\mathrm{CO}_{2}$ 放出量

- 熱帯雨林とパーム農園との $\mathrm{CO}_{2}$ 吸収能力の比較

(2) 農園開発に伴う $\mathrm{CO}_{2}$ 放出量

- 熱帯雨林の伐採

・泥炭地開発

・火桨による $\mathrm{CO}_{2}$ 放出量

焼畑および野焼きにより引起こされる森林火焱， 泥炭地火桨など

\section{$2 \cdot 1$ パーム油製造時の $\mathrm{CO}_{2}$ 放出量}

$2 \cdot 1 \cdot 1$ パームの種苗・栽培時から搾油までの $\mathrm{CO}_{2}$ 放出量

軽油などの石油製品製造時に放出される $\mathrm{CO}_{2}$ 量の試 算においては油田開発（油田掘削，油井関連インフラお よびパイプライン建設など）の部分を含めず，いわゆる Well to Tank（油井から製品夕ンクまで）で評価するの が一般的である。そこで既存農園でのパーム油製造にお いても石油製品と同じ考え方で（Firm to Tank：農園か ら製品タンクまで） $\mathrm{CO}_{2}$ 放出量の評価が可能であり，こ の結果をパーム油が本来持っている製造時の環境負荷の レベルと見なすことができる。既存農園でのパーム油製 造に係る $\mathrm{CO}_{2}$ 放出量試算に関しては, CSIRO (Commonwealth Scientific and Industrial Research organiza- tion：オーストラリア連邦科学産業研究機構）の報告が ある5)。オーストラリアではナタネ油を原料にして製造 される BDF (Bio-diesel fuel : バイオデイーゼル燃料) が主流であるが, Natural Fuels Australia 他の企業から マレーシアよりパーム油を輸入しパーム BDFを製造し たいとの申請があった。そこで，パーム油の環境への影 響を事前評価する目的で $\mathrm{CO}_{2}$ 放出量を LCA（ライフサ イクルアセスメント）の観点から評価した例である。な お，この報告書での評価対象はパーム油，ナタネ油の 他，対照として軽油も取り上げている。CSIROでの パーム油, ナタネ油および軽油製造時の $\mathrm{CO}_{2}$ 放出量を Fig. 1 に縓めた。

軽油製造における $\mathrm{CO}_{2}$ 放出量は, 軽油 $1 \mathrm{~kg}$ 当り, 原 油生産と海上輸送で $0.215 \mathrm{~kg}$, 石油精製工程で $0.442 \mathrm{~kg}$, 合計で $0.656 \mathrm{~kg}$ と算出される。一方，パーム油製造にお ける $\mathrm{CO}_{2}$ 放出量は，パーム油 $1 \mathrm{~kg}$ 当り，パームの種 苗・栽培で $0.34 \mathrm{~kg}$ ，果実の収穫と搾油で $0.002 \mathrm{~kg}$ ，パー ム油の合計では $0.342 \mathrm{~kg}$ の結果となっている。このこと から，既存の農園で製造されるパーム油は軽油より $\mathrm{CO}_{2}$ 放出量が少なく環境に優しいといえる。

一方，パーム油とナタネ油との比較（植物油を $1 \mathrm{~kg}$ 製造する際に放出される $\mathrm{CO}_{2}$ の総量比較) でも，パー ム油が $0.342 \mathrm{~kg}$ であるのに対しナタネ油では $1.12 \mathrm{~kg}$ で あり，パーム油製造時の $\mathrm{CO}_{2}$ 放出量はナタネ油製造時

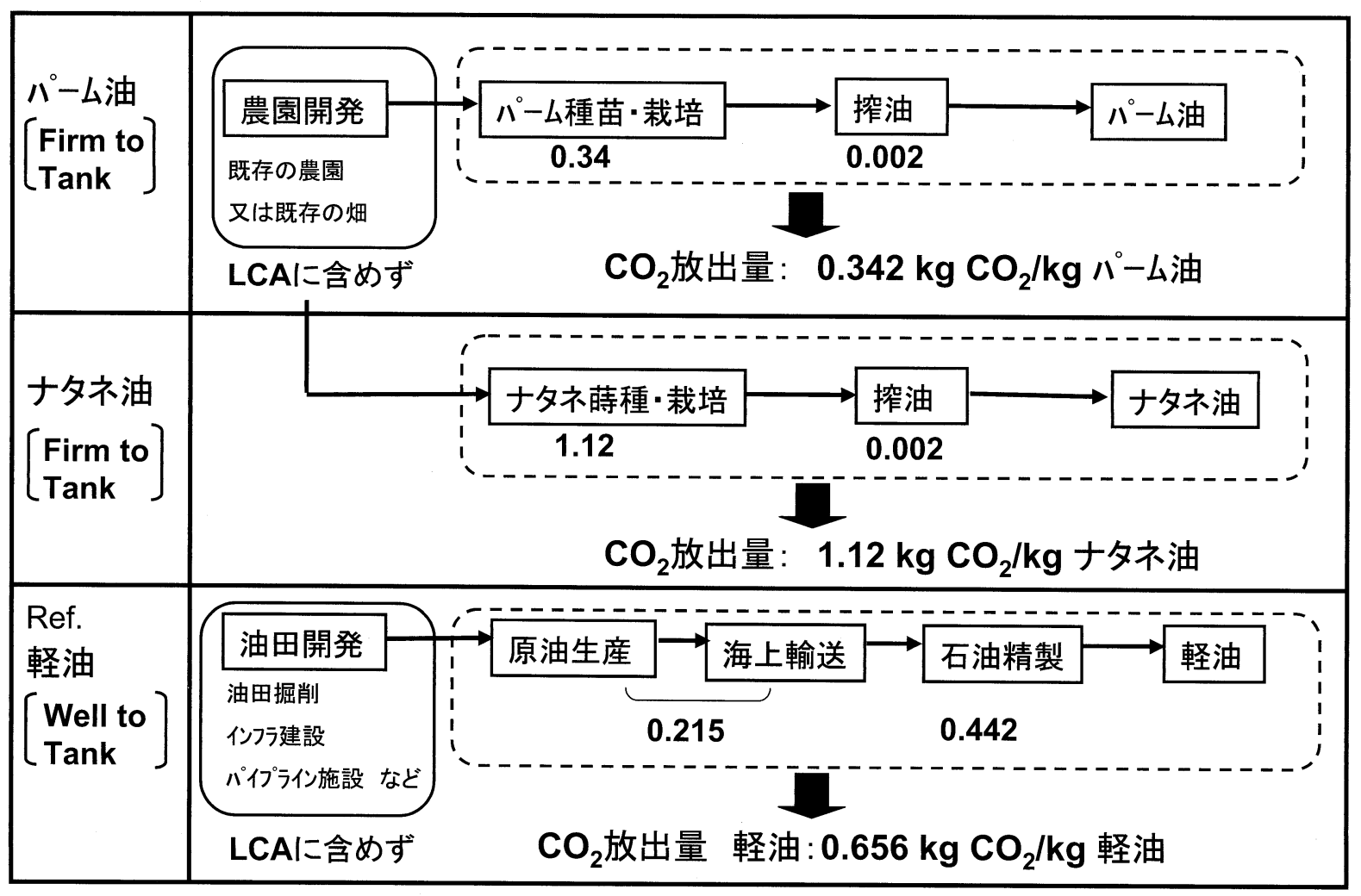

Fig. 1 パーム油およびナタネ油の製造時の $\mathrm{CO}_{2}$ 放出量 
の約 3 分の 1 と少なく, 他の植物油脂と比較してもパー ム油は環境に優しいことがわかる。パーム油とナタネ油 との $\mathrm{CO}_{2}$ 放出量の差は, 栽培時の施肥量に起因する。 ナタネの栽培ではパームに比べ多量の肥料が必要であ り，石油から肥料を製造する時に放出される $\mathrm{CO}_{2}$ 量が 異なるためである。

$2 \cdot 1 \cdot 2$ 熱带雨林とパーム農園との $\mathrm{CO}_{2}$ 吸収能力の比較 パーム油を製造するためにはパーム農園を開発する必 要がある。パーム農園の形態としてはゴム農園からパー ム農園への変換，畑などの農作地をパーム農園化する， あるいはまったく新規に森林を伐採しパーム農園に造成 するなどの手法が取られる。その時に問題となるのが植 物の種類による大気中の $\mathrm{CO}_{2}$ 吸収能力の違いである。 パーム農園にすることにより大気中の $\mathrm{CO}_{2}$ 吸収能力が 低下すれば結果としてパーム農園化により大気中の $\mathrm{CO}_{2}$ 濃度が上昇することになる。

植生による $\mathrm{CO}_{2}$ 吸収量の比較に関しては, Indian Forest Service (インド森林局) の報告 ${ }^{7)}$ に記載がある。 この報告では植生を耕作地（ナタネやダイズ畑も含めた 農地), 2 次林 (営林などの人為的な林), 混交林 (自然 林, 熱带雨林がこの分類に含まれる) 拈よび単純林 (パーム農園がこの分類に含まれる) の 4 つに分類し， 各植生について 1 ha 当たりの年間の炭素固定量が記載 されている。これによれば, 熱帯雨林の炭素固定量は 2 $\sim 4 \mathrm{t} / \mathrm{ha}$, 年 $\left(\mathrm{CO}_{2}\right.$ 換算で $7 \sim 14 \mathrm{t} / \mathrm{ha} \cdot$ 年 $)$ に対し， パーム農園ではその約 2 倍の $5 \sim 9 \mathrm{t} / \mathrm{ha} \cdot$ 年 $\left(\mathrm{CO}_{2}\right.$ 換算 で $18 \sim 33 \mathrm{t} / \mathrm{ha} \cdot$ 年) であり，パーム農園の $\mathrm{CO}_{2}$ 吸収量 は熱带雨林より優れる結果となっている。熱带雨林の場 合は大気中の $\mathrm{CO}_{2}$ を吸収しバイオマスとして固定する 量も多いため, 結果としてパーム農園より地球温暖化防 止に有効な $\mathrm{CO}_{2}$ 吸収量が低くなると考えられる。

一方，インドネシアパーム油協会の報告 ${ }^{8)}$ では熱带雨 林とパーム農園の $\mathrm{CO}_{2}$ 吸収量を直接比較し, 熱帯雨林 の $9.62 \mathrm{t} / \mathrm{ha}$ ・年 $\left(\mathrm{CO}_{2}\right.$ 換算 $)$ に対しパーム農園ではその 約 2.5 倍の $25.71 \mathrm{t} / \mathrm{ha}$ ・年 ( $\mathrm{CO}_{2}$ 換算) と報告している。 パームは高さが $10 \mathrm{~m}$ 以上にもなる樹木のために大気中 の $\mathrm{CO}_{2}$ 吸収能は大きく, 同じ油脂植物でもナタネやダ イズなどの低草木類 $\left(\mathrm{CO}_{2}\right.$ 吸収能は最大でも $7 \sim 14$ t/ha と推定される）と比較しても優位である。

\section{$2 \cdot 2$ 農園開発に伴う $\mathrm{CO}_{2}$ 放出量}

パーム油の増産に必要な農園開発は, ゴム園などから の転作, 遊休地や未利用地の活用などが地球環境から見 て好ましいが，近年のパーム油増産に対しては熱帯雨林 や泥炭地の開発が目立って増加している。

$2 \cdot 2 \cdot 1$ 熱带雨林の伐採による $\mathrm{CO}_{2}$ 放出量について

熱帯雨林伐採に伴う $\mathrm{CO}_{2}$ 放出量推算に関しては, 熱
帯雨林のバイオマス蓄積量が計算の基礎となる。熱帯雨 林のバイオマス蓄積量については地域（アジア，アフリ カ, アメリカなど), 地理的条件 (大陸部か島か) また 気候条件 (降水量, 雨期/乾期の長さ) によっても異な る。そこで, 熱带雨林の地上部のバイオマス量をアジア の群島部で雨季が長く, バイオマス蓄積量の多い地域の 平均值である炭素換算で $300 \mathrm{t} / \mathrm{ha}^{9)}$ を採用し, 熱帯雨林 伐採時に放出される $\mathrm{CO}_{2}$ 量を森林に蓄積されたバイオ マス量の損失と同じ扱いとすれば， $300 \mathrm{t} / \mathrm{ha}$ (地上部の バイオマス炭素量 $) \times 44 / 12\left(\mathrm{CO}_{2}\right.$ への分子量換算 $)=$ $1,100 \mathrm{t} \mathrm{CO}_{2} / \mathrm{ha}$ と計算される。パーム油の生産性を 4 t/ha とすれば，パーム油 $1 \mathrm{~kg}$ あたりの $\mathrm{CO}_{2}$ 放出量は, $275 \mathrm{kgCO}_{2} / \mathrm{kg}$ パーム油となる。この結果より, 熱帯雨林 を伐採して開発したパーム農園で製造されるパーム油の $\mathrm{CO}_{2}$ 放出量は農園開発の部分も含めれば $275.3 \mathrm{kgCO}_{2} / \mathrm{kg}$ パーム油となり, 軽油製造時の $\mathrm{CO}_{2}$ 放出量 $0.656 \mathrm{kgCO}_{2} /$ $\mathrm{kg}$ 軽油を大きく上回り, 熱帯雨林伐採による農園開発 は環境に良くないことがわかる。

一方, IPCCC (Intergovermental Panel on Climate Change：気候変動に関する政府間パネル）では, 土地 利用変化に伴う環境への影響に関して詳細な報告書を公 表している ${ }^{9,10)}$ 。前述の CSIROの報告書ではこれらの記 述内容をまとめ, 熱帯雨林の伐採（ただし，野焼きをせ ず）により造成されたパーム農園で製造されるパーム油 の $\mathrm{CO}_{2}$ 放出量について, パーム農園の生産寿命が 50 年 としてもパーム油 $1 \mathrm{~kg}$ 当たり約 $27 \mathrm{kgCO}_{2}$ と示してい る ${ }^{6)}$ 。つまり熱带雨林を伐採してパーム油を製造した場 合, 森林伐採の影響は長期に渡り, $\mathrm{CO}_{2}$ 放出の点からも その影響ガ大きいと警告している。ちなみに, 前述の計 算で得られる数值をパーム農園 50 年間のクレジットに 換算すると（50 年間のパーム油生産量は $200 \mathrm{t})$, パーム 油 $1 \mathrm{~kg}$ 当たり $5.5 \mathrm{kgCO}_{2}$ となる（ただし，1 ha の農園で のパーム油生産量を 50 年間で $200 \mathrm{t}$ と仮定)。この IPCC の数值とバイオマス量に基づいた計算との差は以 下のように考えられる。

森林伐採の影響は伐採した場所に留まらず，周囲の森 林に悪影響を与え，たとえば伐採時の $\mathrm{CO}_{2}$ 放出が一時 的に周囲の森林の温度上昇に繋がり, その結果 $\mathrm{CO}_{2}$ 吸 収能が低下することも考慮する必要がある。また, 伐採 した木材搬出のためには道路建設が必要であり, 道路建 設時にも $\mathrm{CO}_{2}$ エミッションが発生するなど森林伐採の 影響が多岐にわたり，地球環境への影響が大きいことを 示している。この他にも森林伐採の影響は, 降雨による 伐採跡地の土壤流出や風化なども考慮する必要があり, 地球環境への影響は温暖化に留まらないと指摘されてい る。 


\section{$2 \cdot 2 \cdot 2$ 泥炭地の開発で放出される $\mathrm{CO}_{2}$ 量}

泥炭は湖沼周辺の植物の死骸が水中に堆積したもので あり石炭の前駆体でもある。泥炭地は冷温帯泥炭地と熱 帯泥炭地に分類される。冷温帯泥炭地の例としてはシベ リア，カナダ北部，ドイツおよび日本の石狩地方などが ある。この冷温帯泥炭地の場合は, 晚秋から早春に掛け て雪や氷で覆われているため泥炭の乾燥による $\mathrm{CO}_{2}$ 放 出はないが，夏になって雪や氷が溶け，土地が乾燥する と泥炭が空気中の酸素で酸化され $\mathrm{CO}_{2}$ が放出される。 つまり冷温帯泥炭地の場合は $\mathrm{CO}_{2}$ 放出に季節変動があ るという特徴を持っている。また, 冷温帯泥炭地の泥炭 層は浅く平均して地表から $1.5 \mathrm{~m}$ と言われている。これ に対して，熱帯泥炭地では年間を通して高温多湿のため 一年中その表面は湿っており，開発をしなければ年間を 通して $\mathrm{CO}_{2}$ の放出はないと言われている。また熱帯泥 炭地では植物の代謝速度が速いため炭素貯蔵量が多く, 泥炭層の深さは地表から約 $5 \mathrm{~m}$ にも達している。した がって, 熱帯泥炭地を開発（泥炭地を覆っている森林を 伐採し, 空堀を掘削して水分を排水し土地を乾燥させ る）することにより大量の $\mathrm{CO}_{2}$ が放出されることにな る。この熱帯泥炭地は世界合計で約 4,200万 ha（冷温帯
泥炭地は世界で約 3 億 5,899 万 ha）に達し，その内の $50 \%$ に相当する $1,600 \sim 2,700$ 万 ha がインドネシアに分 布している。さらにこのインドネシアの泥炭地の約 50\%がカリマンタンとスマトラ島にそれぞれ分布してい る ${ }^{11)}$ 。この意味で, カリマンタンは保護価值の高い土地 とされている。

インドネシアの，とくにカリマンタン（ボルネオ島の インドネシア領）での泥炭地開発に対して警告を与える 目的で，2006 年 12 月に国際 NGO（国際湿地保全連合, 本部オランダ）が「Peat- $\mathrm{CO}_{2}-$ Assessment of $\mathrm{CO}_{2}$ emissions from drained peat-lands in South-east Asia (東 南アジア泥炭地から放出される $\mathrm{CO}_{2}$ 量の評価)」と題す

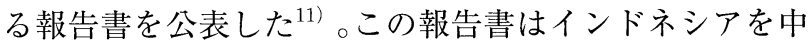
心とした東南アジア泥炭地での $\mathrm{CO}_{2}$ 放出量を調査した 文献を基に，泥炭の乾燥により放出される $\mathrm{CO}_{2}$ 量を推 定したものであるが，この報告書の社会に与える影響は 大きく，とくに欧州を中心にパーム油の Reputation Risk（風評被害）となり，日本でも多くのメデイアが取 り上げている。この報告書によれば，泥炭地からの $\mathrm{CO}_{2}$ 放出量は，泥炭表面水（Water Table）の深さに比例 し，深さが $1 \mathrm{~m}$ になると 1 ha あたり年間 $90 \mathrm{t}$ （本文中で

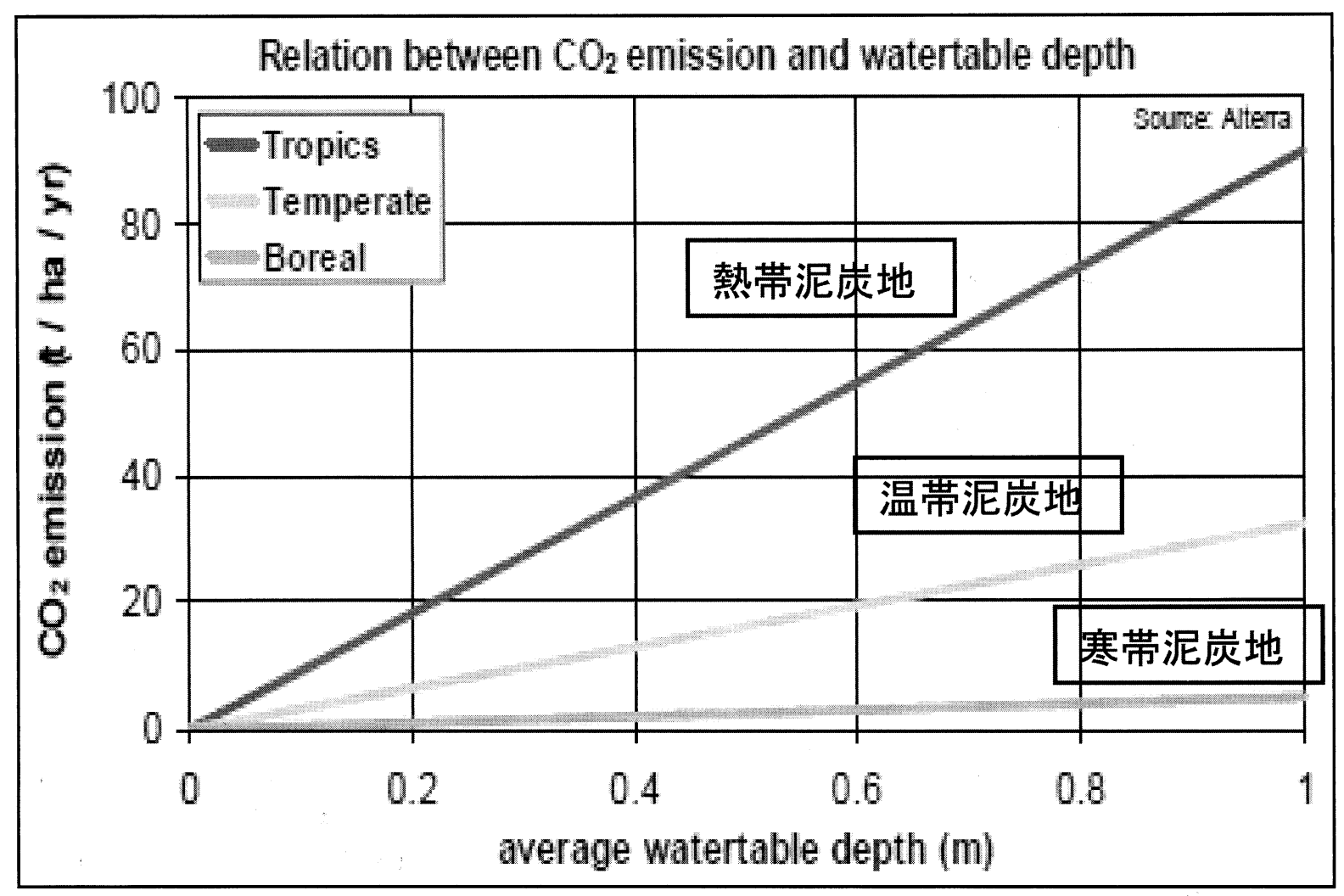

図の出典 : “Peat $\mathrm{CO}_{2}$-Assessment of $\mathrm{CO}_{2}$ emissions from drained peatland inSoutheast Asia", NGO Wetland International, December 2006.

Fig. 2 泥炭地の表面水レベルと $\mathrm{CO}_{2}$ 放出量 
は年間約 $100 \mathrm{t}$ と記述）の $\mathrm{CO}_{2}$ が放出されるとしてい る。ただし, 表面水の深さが同じ $1 \mathrm{~m}$ であっても温帯泥 炭地では年間約 $30 \mathrm{t}$ の $\mathrm{CO}_{2}$ が，また冷帯泥炭地では年 間の $\mathrm{CO}_{2}$ 放出量は $10 \mathrm{t}$ 以下と少ない。これは泥炭に含 まれる炭素量の違いによるもので, 熱帯泥炭地では植物 の代謝速度が速いため泥炭に含まれる炭素分が多いこと に起因する。このことから熱帯泥炭地の開発は乾燥した 泥炭からの $\mathrm{CO}_{2}$ 放出量が多く, 環境への悪影響が大き いと警告している。また，この数值を用いてインドネシ ア泥炭地からの $\mathrm{CO}_{2}$ 放出量の推定とインドネシアの森 林に取り付けてある $\mathrm{CO}_{2}$ 濃度測定器の実測として泥炭 火災での $\mathrm{CO}_{2}$ 放出量も計算している。

その結果, インドネシア全体の泥炭地からの $\mathrm{CO}_{2}$ 放 出量は年間で 5 億 1,600 万 $\mathrm{t}$, 泥炭地火災で発生する $\mathrm{CO}_{2}$ は年間 $14 \sim 43$ 億 $\mathrm{t}$, 合計で $20 \sim 48$ 億 $\mathrm{t}$ にも達し 日本の年間 $\mathrm{CO}_{2}$ 排出量約 13 億 $\mathrm{t}$ を大きく上回り, また インドネシアで年間使用される化石燃料からの $\mathrm{CO}_{2}$ 放 出量約 2 億 5,000 万 $\mathrm{t}$ の約 $10 \sim 20$ 倍に相当するとの見 解を示している。また，国際 NGO はすでに開発された 泥炭からの $\mathrm{CO}_{2}$ 放出量を低減化する策として, 開発し た泥炭地から水分を浸みださせ土地を乾燥させるために 掘削した水路を埋め戻すことを提案している。パーム樹 木は $70 〜 80 \mathrm{~cm}$ の深さがあれば根を張り生育可能であ るため, $1 \mathrm{~m}$ の水路を $20 〜 30 \mathrm{~cm}$ 埋め戻すことは可能 であり，これにより 1 ha 当たり年間で $20 \sim 30 \mathrm{t}$ の $\mathrm{CO}_{2}$ 放出を抑制できると計算される。なお，国際 NGO が推 定した泥炭地の表面水深さと $\mathrm{CO}_{2}$ 放出量の関係は Fig. 2 に示した。

一方で，インドネシア・中央カリマンタンの熱帯泥炭 地開発に関しては北海道大学大学院農学研究科・大崎ら
の研究が報告されている ${ }^{11)}$ 。そこで，この報告書を参考 に乾燥した泥炭からの $\mathrm{CO}_{2}$ 放出量を推算した。熱带泥 炭の炭素含有量を $55 \%$ ，泥炭を含む土の比重を 0.13 ，ま た泥炭層の酸化速度を $3 \sim 5 \mathrm{~cm} /$ 年 $(1 \mathrm{~m}$ の泥炭層が 20 年で酸化されるとして）と仮定した場合，泥炭地 1 ha 当たりの年間での $\mathrm{CO}_{2}$ 放出量は以下の式で計算される。

$\mathrm{CO}_{2}$ 放出量 $=(100 \mathrm{~m} \times 100 \mathrm{~m}) \times(0.03 \sim 0.05 \mathrm{~m})$

$$
\times 0.13 \times 0.55 \times(44 / 12)=78 \sim 130 \mathrm{tCO}_{2} / \mathrm{ha}
$$

したがって，この理論計算でも $\mathrm{CO}_{2}$ 放出量は年間約 $100 \mathrm{t}$ 前後となり，NGO 報告書の数值の妥当性が証明さ れる。このことから熱帯泥炭地開発の環境への影響は熱 带雨林伐採より大きく，泥炭地開発は戒めるべきといえ る。

$2 \cdot 2 \cdot 3$ 火災による $\mathrm{CO}_{2}$ 放出量の推算 (焼畑および野焼き により引起こされる森林火災，泥炭地火災など）

野焼きや焼畑による火が熱带雨林または泥炭地に入り 火災が発生した場合は大量の $\mathrm{CO}_{2}$ が放出される。そこ で，森林火災および泥炭地火災発生時の $\mathrm{CO}_{2}$ 放出量に ついて推算した。

(1)森林火災による $\mathrm{CO}_{2}$ 放出量の推算

1997/98に発生したスマトラ島での森林火災につい てインドネシア農業森林研究所の報告書に記載があ る ${ }^{12)}$ 。そこで以下の情報を基に森林火災による $\mathrm{CO}_{2}$ 放 出量を計算した。

・火災による消失面積 : 自然林 (熱帯雨林) 83,743 ha, 二次林 34,666 ha など総計 124,248 ha。

- 森林の炭素密度 : 自然林 (熱带雨林) $306 \mathrm{t} / \mathrm{ha}$, 二 次林 $93 \mathrm{t} / \mathrm{ha}$

森林 124,248 ha が全焼と仮定すると，火災による炭 素発生量は約 2,900 万 $\mathrm{t}$ で $\mathrm{CO}_{2}$ に換算すると 1 億 600

Table 1 RSPO（持続可能なパーム油のための円卓会議）の概要

正式名称：Roundtable on Sustainable Palm Oil [RSPO]

設 立年：2003 年

設立目的：パーム油の供給関係者の協調とステークホルダーとの対話により持続的なパーム油の成長と消費を促進する 会 員 数：世界 291 団体（正会員 206，準会員 83，2008 年1月 18 日現在）

\begin{tabular}{|c|c|c|}
\hline 生産業者（農園） & 46 & $\begin{array}{l}\text { KLK, FELDA，ゴールデンホープ，Kulim，MPOA，インドネシアパーム油協会， } \\
\text { インドネシアパーム油製造協会 など }\end{array}$ \\
\hline $\begin{array}{l}\text { 加工業者（搾油，製油） } \\
\text { 貿易業者 など }\end{array}$ & 83 & ADM，BP，カーギル，三菱商事，伊藤忠商事 など \\
\hline 消費材生産者 & 32 & $\begin{array}{l}\text { ライオン, 花王, サラヤ, コープクリーン，コルゲート，J\& J, ロレアル，ネスレ， } \\
\text { Reckitt Benckiser, ユニリーバ など }\end{array}$ \\
\hline 小売業者 & 23 & アホールド, IKEA, ミグロス, ASDA, カルフール など \\
\hline 銀行，投資家 & 8 & HSBC, IFC, ラボバンク \\
\hline 環境・自然保護 NGO & 9 & Wetland International, WWF など \\
\hline 社会・開発関連 NGO & 5 & Oxfarm International, サウイット・ウオッチ など \\
\hline
\end{tabular}


万 $\mathrm{t}$ にも達する。この数值を消失面積で割ると森林火 災による 1 ha あたりの $\mathrm{CO}_{2}$ 放出量は約 $850 \mathrm{t}$ となる。 (2)泥炭地火災による $\mathrm{CO}_{2}$ 放出量の推算

泥炭地が火災になった場合は泥炭の酸化により $\mathrm{CO}_{2}$ が放出される。そこで泥炭の炭素含有量を $55 \%$ ，泥 炭地の土の比重を 0.13 ，また火災により表面から深さ $10 \mathrm{~cm}$ の泥炭層が消失と仮定すると以下の試算式によ り, 1 ha 当たりの $\mathrm{CO}_{2}$ 放出量は $260 \mathrm{t}$ と計算される。

＜計算式> $(100 \mathrm{~m} \times 100 \mathrm{~m}) \times 0.1 \mathrm{~m} \times 0.13 \times 0.55 \times$ $(44 / 12)=260 \mathrm{t} / \mathrm{ha}$

なお，泥炭層が深さ $30 \mathrm{~cm}$ まで消失した場合の $\mathrm{CO}_{2}$ 放出量は $780 \mathrm{t} / \mathrm{ha} に も$ 達する。一方，未開発の泥炭地が 火災になった場合は，泥炭層が熱带雨林で覆われている ため，熱帯雨林の消失による $\mathrm{CO}_{2}$ 放出量 $850 \mathrm{t} / \mathrm{ha}$ を加 える必要があり，消失深さが $10 \mathrm{~cm}$ の場合は $1,110 \mathrm{t} / \mathrm{ha}$, $30 \mathrm{~cm}$ の場合は $1,630 \mathrm{t} / \mathrm{ha}$ となり，熱帯雨林の火災より 泥炭地火災の方が深刻な影響を与える事になる。

\section{3 持続可能なパーム油に向けた取組み}

パーム油は栽培から搾油までの製造時の $\mathrm{CO}_{2}$ 放出量 は軽油と同等以下であり，かつ大気中の $\mathrm{CO}_{2}$ 吸収能に おいても熱帯雨林より優位であることから環境に優しい ポテンシャルを持っている。しかしパーム栽培に必要な 農園の開発において，とくに農園を熱帯雨林や泥炭地で 開発する場合には森林伐採時や乾燥した泥炭の酸化によ り，また農園開発に野燒きや焼畑の手法を用いる場合に は森林火災や泥炭地火災により大量の $\mathrm{CO}_{2}$ 放出を引起 こし環境への悪影響が懸念される。そこでこれらの問題 を提起者である NGO と同じテーブルで協議し，改善に 向けた具体策の立案・推進を通しパーム油をより環境に 優しく将来的にも持続可能な植物原料として行くために 持続可能なパーム油のための円卓会議（Roundtable on Sustainable Palm Oil : 略称 RSPO）が 2003 年に設立さ れた。RSPOの現在の会員数は世界で 291 団体に達し, パーム農園業者, 搾油業者, トレーダー, パーム油加工 業者，パーム油製品の小売業者の他，銀行，投資家など が会員となっている（Table 1）。

RSPO ではパーム油を持続可能にして行くために，独 自の原則と基準を作成しそれを遵守することが求められ ている。とくに $\mathrm{CO}_{2}$ 大量放出に繋がる可能性のある農 園開発に関しては以下の厳しい原則と基準を作成し， RSPO メンバーがこれを遵守するように働きかけてい る $^{14)}$ 。

(1) 大量の $\mathrm{CO}_{2}$ 排出に繋がる熱帯雨林や泥炭地での
パーム農園開発を即時停止する。

(2) 森林および泥炭地火災を引起す可能性がある野焼 きや焼畑を禁止する。

また，RSPO では最適なパーム栽培手法を推奨してお り, 土壤の栄養分の保持, 最適条件化でのパーム栽培に よる肥料や農薬の使用量低減化を勧めている。また RSPO 基準に従えばパーム油の生産性向上をも期待さ れ，たとえば大企業系農園および政府が運営する農園で はパーム油の生産性は $5.5 \sim 6 \mathrm{t} / \mathrm{ha}$ (東南アジアでの) パーム油の生産性は平均して $4 \mathrm{t} / \mathrm{ha}$ ）の実績ガすでに得 られている。

この様に RSPO では熱帯雨林や泥炭地での農園開発を 抑制し農園開発に伴う $\mathrm{CO}_{2}$ 放出量を削減するだけでな く,より環境に優しいパーム栽培法についても普及促進 を図っている。また一方で，すでに開発された熱帯雨林 に関しては，動物などの生態系保護と伐採により減少し た森の復活に向けパーム農園内での動物保護区の創設や 植林活動の推進などの取組みも行っている。また， $\mathrm{RSPO}$ の原則と基準に基づいて開発製造される環境に優 しいパーム油の利用を促進するために第 3 者監査による 認証システムを導入し（RSPO 認証パーム油），ユー ザーに対して RSPO 認証パーム油の購入・利用を推奨し ている。

\section{4 まとめと今後の課題}

パームの栽培から搾油まで一連のパーム油製造過程で 放出される $\mathrm{CO}_{2}$ 量は, 最も一般的なナタネ油や代表的 な石油製品の一つである軽油の製造過程で放出される $\mathrm{CO}_{2}$ 量と比較しても同等あるいはそれ以下であり，また パーム農園の大気中の $\mathrm{CO}_{2}$ 吸収能も他の植生と比較し 優位であることからパーム油の本質は環境に優しい植物 原料と言える。しかし，パームを栽培するために必要な 農園の開発を熱帯雨林や泥炭地で行った場合には，森林 伐採や泥炭の乾燥に伴い大量の $\mathrm{CO}_{2}$ が放出される。つ まり，昨今のパーム油に縓わる環境負荷の議論は農園開 発の手法に関するものであり，乱開発が環境に良くない と戒めている。そこで RSPO では熱帯雨林拉よび泥炭地 での農園開発に歯止めをかけ，RSPO の精神・基準を遵 守している農園からのパーム油購入を推進している。

パームは赤道を中心に北緯 17 度から南緯 20 度で成育 する熱帯性植物であり，パーム農園の開発候補地には問 題とされている熱帯雨林や熱帯泥炭地が多く含まれてい る。今後の世界人口増加による食油需要のさらなる増加 は生産性の高いパーム油の需要をさらに喚起すると考え られるが，これに必要な農園開発は既存農耕地での転 作，遊休地や未利用地の有効活用を優先させるとして 
も，農園面積の不足は避けられない。そこで，新たな農 園開発を行わず既存の農園で単位面積当たりのパーム油 の生産性を上げていく技術が必要になる。たとえば 2006 年度のパーム油生産量は平均単収 $4 \mathrm{t} / \mathrm{ha}$ で 3,200 万tであるが，RSPO 管理農園では単収 $6 \mathrm{t} / \mathrm{ha}$ の実績も あり, さらに品種改良も加えることにより最大 $8 \mathrm{t} / \mathrm{ha}$ も 可能といわれている。したがってパーム油の単収が将来 的に $8 \mathrm{t} / \mathrm{ha}$ まで向上すると仮定すれば，新たな農園を開 発しなくとも生産量は 3,200 万 $\mathrm{t}$ から約 2 倍の 6,400 万 $\mathrm{t}$ まで増やすことができると計算される。このパーム油の 増産分は年間一人当たりの油脂消費量を日本人並みの $20 \mathrm{~kg}$ とすると 16 億人分に相当し, 地球人口が現在の 63 億人から 2020 年予測の 75 億人に増加してもパーム 油の增産だけで対応できることになる。また，単収増加 による効果はパーム油製造時の $\mathrm{CO}_{2}$ 放出量の削減にも 繋がり，人口問題と環境問題の雨面から栽培法や農園管 理法の改善による単収増加を進めていく必要がある。

また一方で，パーム油の製造が既存農園の既得権とな る可能性もあり，自然および生態系と共存可能なパーム 農園の開発手法を考案することも重要である。たとえば 熱带雨林については, これまでのようにすべての森林を 伐採除去するのではなく，農園開発予定面積の 20 30\%を熱带雨林のまま残しパームと森林との共存をはか ることがRSPO メンバー農園でも進められている。農園 ライフサイクルでの $\mathrm{CO}_{2}$ バランスと生態系の保護を両 立させることによりパーム油をより環境に優しく持続可
能な資源としていくための試みがさらに発展して行くこ とを期待している。

\section{文献}

1）(社）日本植物油協会ホームページ（出典はオイルワー ルド誌）http://www.oil.orjp/seisan/seisan02-01.html

2) 油脂, $58(9), 28-9$ (2005).

3）オレオケミカル年鑑 2007 (CMC)

4) 油脂, 61 (1), 20-3 (2007).

5）(財)石油産業活性化センター, 石油・ LNG - 石炭のラ イフサイクルインベントリー（LCI）比較について (1998)

6) T. Beer, T. Grant \& K. Cambell, CSIRO Report, KS54C/ 1/F2.27, August (2007).

7) D. N. Pandey, Climate Policy, Indian Forest Service, Bhopal India, pp. 367-77 (2002).

8) E. Lamade \& J-P. Bouillet, DOSSIER OCL VOL, $12 \mathrm{~N} 2$ MARS-AVRIL pp. 154-60, 2005.

9) IPCC Good Practice Guidance for LULUCF, Chapter 3, Annex 3A.1

10) IPCC Special Report on Land Use, Land-use Change And Forestry

http://www.grida.no/climate/ipcc/land_use/index.htm

11）大崎ほか, 日本熱带生態学会ニューズレター, No. 42, 28 (2001).

12) A. Hooijer, M. Silvius et al., Delft Hydraulics Report Q3943, No. 12, 7 (2006).

13) D. Murdiyarso, M. Widodo \& D. Suyamto, Sci. in China, 45, 65 (2002).

14) RSPO Prinaciples and Criteria for Sustainable Palm Oil Production, (10), 17 (2005). 